\title{
The Guise of the Bad in Augustine's Pear Theft
}

\author{
Hans Bernhard Schmid ${ }^{1}$
}

Accepted: 23 January 2017 / Published online: 2 December 2017

(C) The Author(s) 2017. This article is an open access publication

\begin{abstract}
In the second book of his Confessions, Augustine of Hippo presents his famous juvenile Pear Theft as an apparent case of acting under the guise of the bad. At least since Thomas Aquinas' influential interpretation, scholars have usually taken Augustine's detailed discussion of the case to be dispelling this "guise of the guise of the bad", and to offer a solid "guise of the good"-explanation. This paper addresses an important challenge to this view: Augustine offers two different "guise of the good"-explanations in his text rather than just one, and the two explanations seem to be mutually exclusive. A number of more recent attempts to reconcile Augustine's two lines of explanation are discussed and found wanting, and a new suggestion is made. The proposed solution focuses on the Pear Theft as a joint action, and it departs from the Aquinian interpretation in that it accounts for a way in which the "guise of the bad"-hypothesis survives the explanation.
\end{abstract}

Keywords Evil · Guise of the good · Joint action · Augustine · Aquinas

In the second book of his Confessions, Augustine of Hippo famously recounts how one night in his sixteenth year, he teamed up with a couple of friends to break into a neighbor's garden:

"There was a pear tree close to our own vineyard, heavily laden with fruit, which was not tempting either for its color or for its flavor. Late one night - having prolonged our games in the streets until then, as our bad habit was - a group of young scoundrels, and I among them, went to shake and rob this tree. We carried

I'm grateful to the participants of the Guise of the Bad-Workshop at the University of Vienna, the participants of an academia.edu session on a draft version of this paper as well as to two anonymous referees for many helpful suggestions.

Hans Bernhard Schmid

hans.bernhard.schmid@univie.ac.at

1 Department of Philosophy, University of Vienna, Universitätsstraße 7, A-1010 Vienna, Austria 
off a huge load of pears, not to eat ourselves, but to dump out to the pigs, after barely tasting some of them ourselves." (II, iv, 9)

An obvious reason why Augustine notoriously "goes on and on" (Russell 2004 [1946], p. 323) about this is that it is a sort of re-enactment of the biblical "original sin" - a concept that Augustine introduced in Christian theology shortly before writing his Confessions (cf., e.g., Boyce 2014, chap. 3). Yet in several respects, Augustine's Pear Theft seems to depart rather remarkably from Eve's and Adam's eating from the Forbidden Tree, as reported in Genesis 3. One of the most striking discrepancies is this: In Genesis 3, Eve decides to eat the apple because "the serpent" told her that there is something valuable in it for her: "your eyes shall be opened, and ye shall be as gods, knowing good and evil" (Genesis 3, 5). Eve then judges that in spite of God's command not to eat from the tree, the tree is "good for food" after all mostly because it is "a tree to be desired for making one wise" $(3,6)$, she eats and passes the apple on to Adam. Thus Eve clearly eats from the Forbidden Tree for a (subjectively) good reason: she wants to make cognitive progress and become a competent user of normative distinctions. ${ }^{1}$ We can thus understand Eve, even if we may think she was wrong and wish she had decided differently (or perhaps that God had been a bit more accommodating to her cognitive aspirations).

The way in which Augustine first presents his own Pear Theft case seems markedly different in these respects. Not only is there no "serpent" in his story - the boys seem to have come up with the idea all by themselves. They also seem to have no subjectively good reason: it is the lack of point of the Pear Theft that Augustine emphasizes most. He suggests that the boys were already competent users of the relevant normative differences, and that they had the knowledge that stealing is wrong written in their heart (II, iv, 9) - no need to commit a fruit theft for knowledge of good and evil. He further emphasizes that the fruit was "not tempting either for its color or for its flavour" (ibid.), and that the boys knew from the outset that much better pears were readily available to them from Augustine's parents' own orchard. It is not, Augustine suggests, for some gain that the boys committed the theft - Augustine has the boys end up feeding the inedible stolen pears to the pigs. "I ask what delighted me in the theft, and I find no item" (II, vi, 12), Augustine says, and he states - addressing God, as the Confessions are written as a prayer: "Let my heart tell Thee what it sought there, that I should be gratuitously evil, having no temptation to ill, but the ill itself" (II, iv, 9). Bereft of any other explanation, Augustine sees himself faced with the thought that the whole point of the Pear Theft may just have been this: committing a theft just for the sake of stealing, with no further purpose in mind.

While Genesis 3 has Eve acting under the guise of the good, Augustine thus presents us with the idea of acting under the guise of the bad: doing what is wrong for no other purpose, and under no other description, than its being wrong. This is a different issue, and as

\footnotetext{
${ }^{1}$ Attentive readers of Genesis 3 have sometimes wondered how Eve can make the judgment that the apple is "good for food" before "knowing good from evil". In a one-page paper (La Croix 1984), this is called the "Paradox of Eden" - either Eve cannot judge and is thus not guilty, or she judges and is plain stupid - though most interpreters think that there is a reading that is more favorable to the text. In this reading, Eve has, from her creation, some primitive "knowledge of good" that differs from a more elaborate sort of "knowledge of good" that she acquires by eating, and that implies "knowledge of evil". It is on the base of the primitive non-differential "knowledge of good" that she makes her judgment (cf., e.g., Stern 1958). Whatever line one takes on the circularity issue, Genesis 3 has Eve acting under the guise of the good - she eats the apple because she wants to make cognitive progress. She knows that this is against God's command, but it is clearly not because it is against God's command, but in spite of God's command that she acts.
} 
Augustine's interpreters have rightly pointed out, Augustine's Pear Theft tale is thus a challenge of the Platonic "guise of the good"-principle even more than it is a dialogue with Genesis 3. Rather than just looking at the Bible for further explanation of Augustine's problem, it is important to include Plato.

In Meno (cf. esp. 77c f.), Plato has his Socrates arguing for the view that where people do bad things they do so believing them to be good rather than knowing them to be bad, supporting this view with the argument that what is bad is harmful and miserable, and nobody wants to be made harmful and miserable. This sounds like an empirical claim about human psychology - and a somewhat dubious one at that -, and Augustine, who is far from letting the "guise of the good"-principle go light-heartedly, since it fits his project "to Platonize Christian theology" and to identify Plato's idea of the good with the Christian God (cf. Jaspers 1962) quite well - makes Plato's point stronger by putting it in theoretical terms. Crimes, he argues, are actions, and actions require reasons. In order to act for a reason, however, the agent needs to see the action as desirable or worthwhile doing according to some however lowly conception of the good.

"When $[\ldots]$ we inquire why a crime was committed, we do not accept the explanation unless it appears that there was the desire to obtain some of those values which we designate inferior, or else a fear of losing them. For truly they are beautiful and comely, though in comparison with the superior and celestial goods they are abject and contemptible. A man has murdered another man - what was his motive? Either he desired his wife or his property or else he would steal to support himself; or else he was afraid of losing something to him; or else, having been injured, he was burning to be revenged. Would a man commit murder without a reason, simply for the sake of committing a murder? Who would believe such a thing?" (II, v, 11).

Augustine's concern is with the intelligibility conditions of action. In order to understand a crime, there has to be a way to make sense of it in terms of ways the act appeared, to the agent and at the time of acting, as good according to however lowly a conception thereof. A way of making the point even stronger - moving beyond Augustine's text - is to see action under the guise of the bad not only as unintelligible, but indeed as a paradox. Here is a way to illustrate this view. The attitude " $\Phi$ is utterly bad, but I intend it" is paradoxical in the same Moorean way as "P is false, but I believe it" (for Moore's original Paradox, cf. Moore 1993). It is a contradiction in commitments: by intending to $\varphi$, the agent is committed to some good in $\varphi$ ing in the same way as in believing that $\mathrm{p}$, the agent is committed to the truth of $\mathrm{p}$. Recent philosophical research has pointed out a number of ways in which such apparently paradoxical attitudes may actually occur (cf. Coliva 2015), and for the practical version, Aristotle (EN VII, esp. 1146b-1147b) already pointed out that we quite frequently intend things even though we know that - all things considered - they are comparatively bad. Yet even where we are weakwilled, as in Aristotle's case, it is not that we act under the guise of the bad, because there is some good in acting accordingly, even though the good in question is not the best, all things considered. The smoker who lights another cigarette may do so knowing this is bad, all things considered - but he or she still does so for a reason, which is the satisfaction of his or her craving. In his Pear Theft tale, Augustine is careful in pointing out that his case is different: it is not a case of succumbing to temptation. It is not in spite of their knowledge that it is bad that they steal the pears, but because of it. And it is not because the agents misconceive of the good 
(e.g., thinking stealing is good, when it is to their own benefit) or misapply the concept (e.g., thinking this is not really a theft) that they do what they do. They know stealing is bad, and they do not do it for the stolen goods.

Recent philosophers who explored the possibility of action beyond the guise of the good or of desiring the bad have sometimes invoked the idea that motivation and evaluation are different stories (and indeed more different than we often think), and that if our motivations usually accord with our evaluative judgments (so that our motivating reasons provide some subjective justification under the guise of the good), this is due to effective (self-)education rather than a conceptual a-priori (Stocker 1979; Velleman 1992). Applying this to the case at hand, one might perhaps take a somewhat Pauline line. In Romans 7, 7ff., Paul famously invokes a psychological theory according to which prohibitions somehow work against themselves by making the prohibited salient in our mind, which attracts our will ("Don't think of an elephant!"). Augustine certainly aims at reconstructing the view taken in Romans, and had there been a "Don't rob this pear-tree!" sign by the neighbor's garden, the case might have been just another such evaluatively unguided, salience-responsive motivational impulse. Yet this is not how Augustine depicts the case; his version is not one of evaluation-insensitive motivation, but rather one in which all the motivation there is seems to come from negative evaluation. It is not the case of motivation that is unguided by evaluation, but rather motivation that seems to be guided by de-, in-, or dis-valuation.

Augustine struggles hard with his Pear Theft. He spends most of book II of the Confessions on the case, and it should be emphasized that we do not find him in a particularly assertive mood in these passages. In our translation of the relevant sections, almost one third of the sentences end with a question mark. If Augustine "thinks in questions", as Karl Jaspers (1962, p. 75) has argued, this is certainly true of his treatment of the Pear Theft.

His interpreters, however, have usually taken Augustine's discussion to terminate in an unambiguous endorsement of the "guise of the good"-principle, and a rejection of the appearance of the guise of the bad in the initial description. The paradigm for this view is Thomas Aquinas' discussion of the case. In paragraph 12 of Question 3 of his de malo, Aquinas addresses Augustine's Pear Theft as one of the main challenges to the sub specie boni-principle. Aquinas' aim is to defend the principle against the view that there is a sort of malice that seeks the bad for its own sake. Aquinas puts the issue as follows: "Augustine says in his Confessions that when he happened to be stealing fruit, he loved his delinquency, namely, the very theft not the fruit itself. But to love evil itself is to sin out of malice. Therefore, a person can sin out of malice" (q. 3, xii [2003, 178]; cf. Confessiones II, iv, 9: „amavi defectum meum, non illud, ad quo deficiebam"). This is the view against which Aquinas argues in the following. As always, Aquinas' aim is certainly not to refute Augustine, whom Aquinas treats as an authority, and as such as right a priori. Rather, the aim is to show that what Augustine really means - and indeed says - is compatible with the guise of the goodprinciple, if it is correctly understood. Aquinas takes the tool he uses for this reconciliation project from Aristotle, who in book III of his Nicomachean Ethics presents a core idea of the theory of practical reasoning by arguing that - to put it in Kantian terms - whoever wants an end, thereby also wants the necessary means (and the unavoidable side-effects). It is qua means rather than qua ends, Aquinas argues, that sins can be voluntarily chosen, willed, or perhaps - stretching the term a bit - "loved". The guise of the good-principle remains in place concerning ends: "No one by acting intends evil as the object chiefly willed, and yet the very evil consequently becomes voluntary for a person when the person, in order to enjoy the desired good, does not flee incurring the evil" (2003, p. 179). The good is "primarily and 
chiefly" the goal of action, and only in the "secondary" way in which means and side-effects are willed, too, can it be said that evil can be willed and chosen, as evil. Applying this to Augustine's Pear Theft case, Aquinas argues that the theft, qua theft, was not the primary goal, but rather a means to the goal.

"When Augustine says that he loved his very delinquency, not the fruit that he was stealing, we should not so understand this statement as if the very delinquency or the deformity of moral fault could be primarily and intrinsically willed. Rather, he primarily and intrinsically willed either to exhibit typical behavior to his peers or to experience something or to do something against the rules or some such thing." (q. 3, xii, resp. 1-2 [2003, 180]).

In other words, the Pear Theft was really about avoiding peer pressure, curiosity, and the sheer thrill of committing an illicit act; the theft was merely the means to the goal, and intended as such. Aquinas' view finds much support in Augustine's further discussion of the case. In II, vi-ix, Augustine explains how "going against the rules" may appear, to the agent, as something worthwhile doing. He identifies a specific sort of pride as a motivation in the light of which it seems good to perform a bad action. The claim here is that doing something bad may seem to be an assertion of one's freedom and independence. In order to prove that they are independent and free agents rather than something like servants of the moral law, agents may deem it worthwhile to act against what they, themselves, recognize as the demands of morality.

"What then did I love in that theft? [...] Did I wish even by stealth to do contrary to Thy law, because by power I could not, to that being a prisoner, I might mimic a maimed liberty by doing with impunity things unpermitted me, a darkened likeness of Thy Omnipotency? [...] Did I like what I might not, only because I might not?” (II, vi, 14).

Under labels such as "imitation dei", this has often been taken as the core motivational factor identified by Augustine. The view is that there is something submissive about always doing what seems to be the thing to do, and that this fails to satisfy our desire to assert our agency as our own according to some - perhaps hyperbolic - conception of autonomy. Or, as Anscombe (1963 [1957], p. 75) puts it, the good that is seen in evil is in the "condemnation of good as impotent, slavish, and inglorious", and the affirmation of "my intact liberty in the unsubmissiveness of my will." Augustine devotes much attention to this under titles such as "rebellion against God". 2

In II, xiv-xvi, we find ample evidence for another "guise of the good"-explanation that Aquinas mentions: the desire "to exhibit typical behavior to his peers" in Augustine's account. In these passages, the proto-social psychologist Augustine rises to his finest, and he comes up with a theory of conformist preferences, arguing that peer pressure - the fear of group sanctions - can motivate group members to go along with the group even if they recognize the joint venture to be bad. On this line, "shame not to be shameless" is identified as the key motivating reason, and with this the desire for approval from his peers:

\footnotetext{
${ }^{2}$ In de libero arbitrio (3.76), Augustine gives a more detailed description of how this radical perversion occurs. Even the devil cares for something good, it is argued here; more precisely, it is his own genuine goodness that he cares for, and this distracts him from the contemplation of God as the source of the good he has in mind. He takes delight in his goodness purely as his own, and it is thus that he comes to enjoy his powers in such a way as to imitate God.
} 
"I ran headlong with such blindness, that amongst my equals I was ashamed of not being shameless [...]; and I took pleasure, not in the pleasure of the deed, but in the praise." (II, xvi)

Again, this account is solidly under the guise of the good. The good that is seen in actions of this kind is conformity with the group and the "sweetness of friendship" mentioned earlier in the text (II, v, 10), the pleasures of being recognized as a group member.

Given these motivational explanations - wanting to assert one's own agency rather than slavishly obeying norms, wanting to be recognized as a group member and go along with one's peers - it may thus not seem surprising that Augustine's many interpreters have tended to follow Aquinas' line, arguing that in the last resort, Augustine's take on the Pear Theft is that in spite of first appearances, it was carried out under the guise of the good after all. As far as I can see, almost everybody among Augustine's interpreters agrees that Aquinas is right and that Augustine does give a "guise of the good"-account of the Pear Theft.

The only notable exception I know of is Robert O'Connell (1969, p. 46ff.). O'Connell points out a crucial problem in Augustine's elaborations on the motivations for the Pear Theft, and it is that the two motivations Augustine identifies - the prideful hyperbolic self-assertion of radical freedom, on the one hand, and the shameful self-immersion in the gang (with the partial self-loss it implies), on the other - do not seem to fit nicely together at all. To put the point as succinctly as possible: if young Augustine was so much out to assert his own unbound freedom - why, then, would he have wanted to be down with a gang so much as to cave in to group pressure? This simply does not seem to fit at all, and considering the discrepancy between two lines of thinking about evil in twentieth century that have followed Augustinian paths might illustrate the point. On the one hand, there are the existentialist heirs of Augustine's "facinus gratuitum" and hyperbolic pride, the existentialist writers and philosophers of gratuitous action - the likes of Fjodor Dostoevsky's Stavrogin, André Gide's Lafcadio, or Albert Camus' Meursault, who commit motiveless crimes in order to assert some sort of independence. On the other hand, there are the likes of Hannah Arendt's "Eichmann" and Stanley Milgram's obedient test people, who are so much concerned with conformity that they give up their own independent judgment. It is, it seems, no coincidence that it is difficult to bring those two groups together in one's mind.

If not in quite these terms, the discrepancy highlighted by O'Connell has not escaped the notice of Augustine scholars entirely. And yet, it is obviously generally believed that this can be fixed in a way that is compatible with a "guise of the good"-explanation of the Pear Theft. Following are some examples from more recent research.

i) In his often-quoted "Petit Larceny, the Beginning of all Sin" (1996), Scott MacDonald argues that each of Augustine's two accounts analyzes a necessary condition for the Pear Theft, but that it is only in combination that they are sufficient. In MacDonald's reading, neither of the two accounts can stand alone: "Augustine succeeds in uncovering two motivations for his thievery which, in his analysis, work crucially together. He stole the pears because doing so seemed to him a way of expressing or claiming for himself a kind of limitless freedom and power. But given that that motive was not sufficient by itself to 
move him to the deed, his action also required the motivation provided by his desire to be included in the fellowship of rogues - to love and be loved. These are the two components of the composite motivational state Augustine's analysis of the theft of the pears reveals. Each of these motivating factors constitutes an intelligible motivation of the sort required by Augustine's own account of motivation. Each identifies something that an agent might reasonably take to be a good and therefore take delight in, even if doing so involves significant error or illusion" (1996, p. 65).

The problem of this view is that it does not seem to recognize just how antithetic in spirit the two lines of argument are. To restate the point made above: Why would a prideful limitless self-assertor of the Rebel Without a Cause line of explanation suddenly be so much concerned with being loved by others so as to be moved by shame? If an act is performed with an eye on the approval of others, it seems that it simply cannot be a proper act of self-assertion along the lines of the kind of freedom ascribed to prideful sinners. You're either a Lion or a Sheep, and to the degree that you're sheepish, your lion-like prowess will be compromised.

Other interpreters show more awareness of the fact that Augustine's two explanations are not only different, but seem to be somewhat at odds with each other. There are two obvious approaches to make them somewhat more compatible. The first tinkers with the shame-related account and reconceives of the sociality at work in the second account in such a way that it fits better to the special kind of pride that is in the focus of the first analysis (ii). The second chooses the converse option and tries to modify the conception of pride in such a way that it fits to the sociality requirement argued for in the first account (iii).

ii) In a small but concise and very clear introduction to Augustine, Gareth Matthews (2005) chooses the first option. The crucial element in his reading of Augustine's overall view is the passage in Augustine quoted above as saying that the company of others was important for the explanation in a different way than that the participants' motivation would have been to seek the other participants' approval, or seek some other intrinsic good in their togetherness. In Matthews' view, neither the "sweetness of the bond of friendship" nor the type of aversion against deviance from communal standards implicit in shame, or conformism towards a group ethos, is the ultimate good identified in the motivational explanation of the act. He finds interpretive support for this claim in Augustine's text, where he says the following:

"What fruit had I then (wretched man!) in those things, of the remembrance whereof I
am now ashamed? Especially, in that theft which I loved for the theft's sake; and it too
was nothing, and therefore the more miserable I, who loved it. Yet alone I had not done
it: such as I then, I remember, alone I had never done it. Did I love then in it also the
company of the accomplices, with whom I did it? I did not then love nothing but the
theft, or rather, I did love nothing else; for that circumstance of the company was also
nothing. What is, in truth? Who can teach me, save He that enlighteneth my heart and
discovereth its dark corners? What is it which hath come into my mind to enquire, and
discuss, and consider? For had I then loved the pears I stole, and wished to enjoy them, I
might have done it alone, had the bare commission of the theft sufficed to attain my
pleasure; nor needed I have inflamed the itching of my desires by the excitement of 
accomplices. But since my pleasure was not in those pears, it was in the offence itself, which the company of fellow-sinners occasioned [faciebat]." (II, viii, 16).

What Augustine loved in the act, Matthews takes Augustine to say here, was the sinful act alone, and not the company with others (just as Augustine says explicitly in the last sentence of the above quotation). Matthews argues further, however, that this need not contradict the statement that the company of others was necessary for the act. Rather, he claims, there is a mechanism in which social factor influences the participants' behavior that is different from the desire to belong, and different from mere conformism towards an accepted group ethos. The way in which sociality causally contributed to the act is different from rationalization through reasons. Groups can influence the participants' behavior by simply removing inhibitions, or normative constraints on action, and this is how the consortium "made" (faciebat) the pleasure taken in the act. The comradery between the "scoundrels" did not, according to Matthews' reading, establish a new normative guideline, but rather, it did away with the grip of the old ones. It is not the case that the participants were faced with a kind of tragic choice of either conforming to what the Law inscribed in their hearts tells them about what is right, and face exclusion from the group and forego the enjoyment of togetherness, or to go along with the gang and sacrifice their own conscience, or evaluative judgment about worthwhile goals, to comradery. Rather, what they wanted was to slap morality (and their own conscience) in the face, and all the group did for them was to provide an opportunity to do so.

In this view, the central motivational feature of the Pear Theft is still Rebellion Without a Cause, the desire to throw over the traces of morality, but it is only in consort with others that an agent dares to do so. The company of others whom one knows to be similarly motivated provides a "special thrill", a sort of "exhilaration" that is of a different nature than the comfort of the approval of others; what it provides is rather a freeing from inhibition rather than a reason for action. Matthews argues that this fits the "horrendous horrors of the $20^{\text {th }}$ century the Holocaust, the killing fields of Cambodia, the massacres of Rwanda" (2005, p. 122).

This interpretation softens the apparent conflict between Augustine's two motivational accounts by relaxing the requirements imposed by the social psychological account. The view is not that the perpetrators are conformists who are after each other's approval and do so by more or less willingly performing the nonsensical acts which they believe to be required of them; rather, they are proud Rebels Without a Cause who need each other only in so far as their mutual presence weakens the psychological impact of the moral constraints in such a way as to make acting out their causeless rebellion a real possibility.

Yet it seems that, at least on an interpretive level, this is hardly true to what Augustine says, apart from the last sentence of the above quotation, considered in isolation. Augustine does speak of a particular, intrinsic "sweetness" that even bad friendship has; it is not just that bad friendship removes inhibitions. Rather, it has a "sweetness of its own" (II, v, 10). Also, Augustine does single out shame as a decisive motivational factor - the ominous "shame not to be shameless" - implying that some sort of motivation to conform to a group ethos was decisive. Without these elements playing any role, it seems that more than half of what makes Augustine's account so realistic from a social psychological standpoint is simply discarded. Second - and much more importantly - it seems that Matthews' revision simply misconceives the kind of sociality at work in the Pear Theft paradigm. Along the line of Matthews' reading, one might think that the case was that of an aggregate of individuals in which the mutual structure of recognition was such that each member was doing his own nonsensical and immoral thing, encouraged by the others. My objection is not that this is unrealistic; such 
cases certainly do occur, but this is simply not the case that Augustine describes in the Pear Theft story. It is not true that Augustine stole the pears, while others did their own evil thing. Rather, they stole the pears together. This suggests that the sociality at work is not simply an enabling condition for individual acts of causeless rebellion; rather, it is a feature of that act itself, and this is lost in Matthews' interpretation.

The same objection can be made against Carl G. Vaught's (2003) otherwise impressive account. Vaught, too, claims that the social factor plays a different explanatory role than through the workings of a preference for conformism. He, too, takes Augustine's above statement to say that what Augustine was going for was the sin alone and not anything else such as the "sweetness of friendship" (Vaught 2003, p. 57). Yet the view with which Vaught ends up with is that the "scoundrels" were engaged in a kind of a "Lonely Crowd" along the lines of the role of the peer group of "other-directed" characters depicted in David Riesman et al. (1950) influential sociological analysis. This, however, calls Vaught's initial statement concerning the motivation into question. "Lonely Crowds" are constituted by aggregates of individuals who are other-directed in such a way as to be motivated by conformism. In a Lonely Crowd, each one does his or her own thing, but he or she does so according to what he or she thinks is expected from him or her. Thus conformism is essential, but again, the jointness of the Pear Theft remains entirely unaccounted for. Other-directed characters want to keep up with the Joneses; they do not like to act together with them. This difference between parallel individual action and joint action is crucial.

iii) One of the most interesting and philosophically rich attempts at a unifying account of the Pear Theft is by Colin Starnes (1990).

"It is necessary for the act that it is committed by more than one agent: The reason is the following. The universe will not recognize the freedom and omnipotence which $\mathrm{Au}-$ gustine desired to establish for himself. But in order to be established objectively it must in some way be recognized by someone other than Augustine - unless he was to retreat into idiocy. But by whom? If he had tried to flaunt the deed in front of his parents, or the farmer he had robbed, they certainly would not have let him go unpunished. He could only get the recognition he desired from others who desired and got the same thing from him in return [...]. The creation of a tiny sodality, whose members gave one another the illusion of absolute freedom which the universe denied them in reality. They got the illusion through their complicity in such wanton and destructive acts as the gratuitous theft of pears; by doing unpunished what they knew to be punishable, each one satisfied the other that he had the omnipotence all desired. Such a company, such a gang, was, as Augustine says, a very unfriendly kind of friendship. It was a tiny society which catered exclusively to mutual sin, coming together for no other purpose than to give its members falsely what none could have in truth" (1990, p. 44f.).

The structure of the argument is first, that the agent needs the presence of others because it is a requirement for the act that it be "established objectively" in such a way as to be "recognized" by others. If the act is not recognized by others, it is "idiotic" in a way that undermines its status. Second, recognition by others should be such as not to involve the kinds of reactive attitudes usually displayed towards such acts. The act in question cannot be "established objectively" by agents who disapprove of the action; such attitudes would lead to punishment of the act, and it is not only an accidental 
psychological disposition of the agent that he does not want to be punished; rather, it is essential for the act not to be punished, as an act that is punished would not establish the agent's omnipotence. The solution is that the act should be performed in the presence of agents who are motivated in a similar way, and therefore will not disapprove of the act, but rather approve of it; the argument for this is that if an agent is motivated to establish his own capability to perform a wrong act without being punished, he cannot plausibly have a reactive attitude towards others who are similarly disposed; rather, he will recognize the others' actions in such a way as to establish their objectivity.

This account is particularly fascinating because it takes Augustine's remarks on the role of the consortium between the agents to the level of the theory of recognition, and alludes to present day interpretivism about mind and action. However, it neither seems to be entirely convincing in and of itself, nor adequate to Augustine's case. Following are some critical considerations on each step of this argument.

Why should it be necessary for the evil act to be "established objectively" by being "recognized by others" rather than being performed unobservedly, and ignored by others? What exactly is the problem of the "idiocy" which Starnes mentions? Would it not be more plausible to say of Augustinian prideful Rebels Without a Cause who draw an absolute line between themselves and others that absolute idiocy - in the Greek sense of the word in which it refers to somebody who is unconcerned with the public sphere - is just what they aim for? Think of the twentieth century heirs of Augustine's "facinus gratuitum"-account, the antiheroes of "gratuitous action" in existentialist literature, e.g., Albert Camus' Mersault in his étranger. Meursault is alone with "the Arab" on the beach; by inadvertently shooting "the Arab", he has killed the only potential witness. Even though there is no one around anymore to "objectively establish" his action and to do him the service of recognizing his act, he still performs his gratuitous action: shooting further bullets in order to assert his agency behind what he did not in fact properly "do", in terms of an intentional action. And similarly for André Gide's Lafcadio: he, too, acts without witnesses in an otherwise empty railway compartment, and nothing about the solitary nature of his act seems to undermine his aim to assert his ability to be completely unbound by norms. If there is an "objectivity" that depends on recognition, it does not seem to be any of these agents' concern; in this way at least, they seem to be rather happy to be "idiots" in that sense of the term, and this does make sense: the establishing and asserting of their own agency is self-assertion, and does not depend on mutual recognition, as going against any such external standard is the whole point of the act.

A critical reader might object that this is just a casuistic argument that fails to appreciate the philosophical depth of Starnes' point. One way to try to make sense of Starnes' claim that even "gratuitous" acts cannot be "idiotic", and need to be recognized by others, is along the lines of interpretivism, or communal accounts of rule following. The basic idea can be cashed out in the following way: Whoever acts, has to have a goal in mind. The goal is the content of his or her intention, and it involves an idea of when the conditions of satisfaction of the intention are reached. Thus this content sets a norm that distinguishes between success and failure. A lonely agent, it is claimed, is not able to ascertain the success of his or her action without assuming that a potential observer, who knows what it was that the agent wanted and thus grasps the rule set by the agent's goal, would judge likewise. The reason is that in order to have reason to believe that he or she has carried out his or her act successfully, he or she must see the matter as - in principle at least - open to public scrutiny.

Interpretivists do not usually claim that people cannot act when no one happens to be around to observe and correct them (such as in the case of Mersault or Lafcadio). 
And indeed, any such claim would seem rather implausible. Rather, the claim is that any agent who believes to have acted successfully has to assume that any competent interpreter of his community would agree, were he or she around to observe. What is excluded by the argument is not "solitary action", as it were, that is, actions that are known by the agent not to be observed by anyone. Rather, what is excluded is that an agent be a follower of a "private rule", that is, a rule of which only he himself can, in principle, be a competent interpreter. An agent may make up "his own rule", e.g., by intentionally doing something that is "wrong" according to the public standards, but he cannot, in his right mind, assume that the rule set by this goal is his own in such a way as to apply, in principle, only to himself. The distinction between him- or herself and others, that the evil agent tries to draw, simply cannot be absolute, if the evil agent is to be an agent with goals. But this seems rather close to what Augustine says about the evil agent's motivation: he or she wants to set her own standards. Augustine grants that this attempt is doomed to fail, but evil is not dependent on success in the attempt; it is the attempt itself that is evil.

The problem with Starnes' interpretation is that it turns the evil agent into a rather comical creature, who reasons along the following lines: "I want to perform a wrong act, but I want to do so properly. If I steal the pears all by myself, with nobody observing me, I cannot really be sure that I followed the rules of proper evil action correctly; I better see to it that I find other competent interpreters of the rules of proper evil action so that they can help me establish that my causeless rebellion was carried out properly and was thus a genuine act of causeless rebellion."

The comical element in this line of interpretation lies in the degree to which it makes the agent appear to be concerned with the formal logical generality of the rule set by his goal, on the one hand, and the evil nature of the content of his action, on the other. On the one hand, the agent is seen as trying to establish his own standards of right and wrong; on the other hand, he is seen as recognizing that any standard needs to be general in nature in order to set a proper norm. The agent does aim to establish an absolute distinction between himself and anybody else in terms of the content of his intention. In this respect, he is not worried at all of being an "idiot" in the above Greek sense of the word. At the same time, he undermines this very idea by wanting to have his status established publicly. This does not seem to fit. If an agent aims at establishing his own norms of right and wrong, he or she better assume the authority to establish whether or not his or her act was successful him- or herself, however futile this endeavor may be.

Moreover, the same worry that was raised against the two previous accounts can be addressed against Starnes' view: Starnes, too, seems to misconceive in a rather obvious way of the particular kind of sociality that is at the heart of the Pear Theft Case. Starnes, just as the other interpreters discussed above, makes it appear that the sociality involved in the Pear Theft is simply something like an enabling condition of individual action, rather than an essential feature of the act itself. It is not the case that Augustine has the boys loitering around and encouraging each other to commit random, immoral, nonsensical individual acts. Rather, he has them act in consort, as accomplices in one and the same act. The sociality in question is the feature by which the act is a joint act, one token action which is performed by a plurality of agents.

Thus, it seems fair to say that these interpretations - whatever their independent value may be - have not pointed out a way in which Augustine can reasonably have meant the two motivational strands to work together. O'Connell's point still stands. 
Further reasons for doubt come from the way in which Augustine concludes his lengthy discussion of the Pear Theft at the end of book II of the Confessions:

"Who can unravel such a twisted and tangled knottiness? It is unclean. I hate to reflect on it. I hate to look on it. But I do long for thee, O Righteousness and Innocence, so beautiful and comely to all virtuous eyes - I long for thee with an insatiable satiety. With thee is perfect rest, and life unchanging. He who enters into thee enters into the joy of his Lord, and shall have no fear and shall achieve excellence in the Excellent. I fell away from thee, $\mathrm{O}$ my God, and in my youth I wandered too far from thee, my true support.

And I became to myself a wasteland." (II, x, 18)

This certainly does not sound like Augustine himself thought he had finally sorted it all out, as Aquinas seems to believe. Rather than stating that what first appeared as an act under the guise of the bad has now finally been proven to be under the guise of the good after all, he states that the matter remains "knotty", and he seems to present himself as turning away from the dirty matter in frustration at the futility of his attempts rather than as satisfied with his own explanations. One way of interpreting this is the following: Aquinas may be right in saying that Augustine thinks that acting under the guise of the bad is an inconsistent idea, and he is also right in saying that Augustine identifies a number of "guises of the good" that in his view played a role in the act. But Aquinas ignores that Augustine's motivational considerations are incompatible with each other, and that the Pear Theft, in Augustine's own view, thus remains a challenge.

It is now time to finally come to a positive proposal. Following is an attempt to show how Augustine's two "guise of the good"-explanations work together. It differs from those from received Augustine-scholarship discussed above in that it is not aimed at showing that the Pear Theft is solidly under the guise of the good, but rather at supporting O'Connell's (1969) suspicion in showing how exactly the Pear Theft is and remains a challenge to the "guise of the good"-principle. I do not thereby claim to identify "what Augustine really meant to say" anymore than Starnes, who, in his interpretation, certainly does not mean Augustine to preempt twentieth century interpretivism. Still, I would like to argue that the following has some roots in Augustine's own views.

The point of departure is Augustine's insistence that the Pear Theft could not have been just something he did by himself. He emphasizes this point time and time again, with such insistence that it almost corrupts his otherwise brilliant style:

"By myself I would not have done it - I still recall how I felt about this then - I could not have done it alone [...] I would not have done it alone. [...]. Alone I would not have done it - alone I could not have done it at all. My memory is vivid and clear [...]: alone, I could never have committed that theft" (viii, 16).

One way to make sense of this is that it is essential to understand for the way in which the Pear Theft challenges the "guise of the good"-principle that it is a joint action. Joint action has recently become the topic of an extended debate in philosophical research and neighboring 
fields, and though the analyses given in the literature differ widely from each other, there seems to be a widely shared agreement that while joint actions require a plurality of active individual agents, they are not just aggregates of individual actions. It is true that joint actions require each participant to act; but they also require all of them to act together in such a way that it is not just a plurality of actions, but one token action which they jointly perform. ${ }^{3}$ Thus there are at least two ways to ask the "guise of the good"-identifying "why did you do it?"question, where joint actions are concerned: The "why"-question aimed at identifying the guise under which the joint action seemed to make sense as a token joint action, and the "why"-question aimed at identifying the motive for each individual participation. These questions are not independent of each other. In paradigmatic cases of joint action, the answer to the question of why I, as a participant, do my individual part, will identify the way in which in my view, there is a point in the token joint action as such. It is because I see something worthwhile in what we are doing that $I$ contribute my part. But not all joint endeavors are of this rationally tightly integrated kind. What Augustine does in the social psychological passages of his analysis is identifying individual motivations that work differently from this mode of reasoning in that they rationalize participation in a joint action independently of an evaluation of the specific token joint action in question. And this seems plausible enough: we much prefer doing something together to always acting alone; we are natural joiners, we do like to cooperate, we crave being engaged in joint activity, as part of groups - and this may lead us, individually, to see a point in participating in joint action even in the absence of any sense that the specific joint action is worthwhile doing.

Yet so far, this explains only how reasons for participation come to be independent of reasons for joint action; it explains how people may go along with joint ventures even though they see no point in them. It does not explain how apparently pointless joint ventures come about. And this is what in the Pear Theft case, Augustine seems to worry most. He fully acknowledges that kids are joiners, and he is also well aware of the well-established fact that kids see a thrill in violating norms and enjoy asserting their agency by committing pranks. Yet this does not alleviate his worries. Rather, the worrying feature remains that the kids did not satisfy their desire for comradery and the thrill of doing something illicit by doing something illicit together that made actual sense in terms of a joint goal. Put bluntly, the question is: why did they go for bad pears, with which they could do nothing but feeding them to the pigs, rather than, for example, stealing a freshly baked pie from the neighbor's window sill, or some such? How is it possible that among a group of agents, a joint plan comes to be adopted that does not seem to make sense by any of the participant's lights, no matter how conformist and thrill-seeking their preferences may be?

Following is an attempt to account for how this may have come to be - an account that preserves the details of the act given in Augustine's text, while adding some new ones. Imagine the following scene. Young Augustine and his comrades are idly strolling along the streets in boredom, each having an intense desire to do something exciting together with the others, and this motivation being common knowledge between them. Moreover, it is common knowledge between them that exciting things are usually forbidden - they come with the thrill of escaping capture. Thus the boys know that they, together, are up to no good - they just do not know what to do. This would be a good occasion for joint reasoning and deliberation on a good plan, and had they done so, they would certainly have come up with a better idea than stealing bad pears and feeding them to the hogs (which may actually have been the best thing

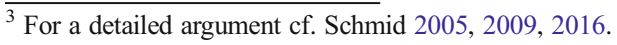


to do with those pears, and which the boys would have soundly rejected had it been assigned to them as a chore). Rather than to reason and deliberate jointly and come up with a plan, they leave it, in some way, up to chance what they are going to do. Here is how this incidental determination of the object of joint action, as it were, might have come about. Assume that among the bored kids, one takes the initiative by climbing the neighbor's fence, perhaps in the light of the idea that what they might be doing together is running through the fields and taking a short cut to some other place where they usually like to loiter around. "Let's do it!", and off they go. Without any clear idea of what it is they might be doing together, everybody goes along and jumps the fence. But one of them stumbles over a ladder; "look what I have found", he shouts, and picks up one end of the ladder. This gives a third one the idea that what they might be doing together is to climb up the pear tree, he grabs the other end of the ladder and points to the tree towards which they then run. Sitting on one of the branches, a fourth one starts to pluck the pears from the tree, eating a bite off it, complaining about its bad taste, much to the merriment of the others, throwing it down, trying another one, finding it bad, too, throwing it down again. A fifth boy catches the pears and collects them. The others join in, plucking the pears and throwing them down. The pear catcher can hardly keep up with catching all the pears; another boy spots a whole pile of baskets stacked behind the neighbor's barn. They seem to come in handy very much indeed, he runs to fetch them, assisting the other boys in catching and collecting the pears. The cooperation is now up and running smoothly; each one has found his role, the feeling of being connected in the flow of a joint activity and the thrill of the illicit is intense, and very pleasing. All of them now have what they wanted: being immersed in illicit joint activity. There is a sense of excitement, and all the boredom has gone. Very quickly, the whole pear tree is bared of all its fruit, all the baskets are filled to their brim. Having done their work, the boys jump down from the branches of the tree, admiring for a moment the filled baskets. What now? Perhaps one of the boys starts to throw pears at one of the other boys, thinking it would be fun to stage a little pear fight; hit by a pear, the other boy screams in pain and throws a pear right back in his opponent's face. Ouch! Not a good idea, this pear fight plan of a joint action! Let's do something else. Checking its weight, one of the boys tries to lift a basket by one of its handle: too heavy to be lifted up by one person alone. Another boy takes the basket by the other handle, now the basket can be lifted off the ground; the boys start to run back to the fence with the basket between them. Another boy spots the pigs in their fence behind the barn. "To the pigs!", he shouts, and together with another boy, he carries a basket to the pigs, lifts the basket and empties its contents to the pigs: great movement among the animals, a lot of noise and action, interesting to watch. The others follow suit, until all the pears are thrown to the pigs.

Contemplating the animals, the boys suddenly hear heavy steps in the grass behind them, accompanied by loud and angry screaming in a frighteningly deep voice. The old neighbor has spotted them! In the blink of an eye, the boys are up and running as quickly as they can, back to the fence, jumping over it: safety! Looking back attentively through the fence, the boys observe the neighbor with a mix of intense fear and excitement: Punishment is now looming; what if the neighbor unleashes his dogs? But the old neighbor is just standing there by the pigs, waiving his stick threateningly in the boys' direction, shouting all sorts of curses and complaints. How hilarious! One of the boys cannot keep his quiet in their hiding behind the fence, he bursts into laughter, and in a moment, there is one big laughter, all of the boys join in, they laugh so hard it hurts, and the louder they laugh, the angrier the neighbor gets, adding even further to the boys' merriment in an escalation of screaming and laughter, until the neighbor - powerless, hurt and beaten - leaves the scene and sadly returns to his home. 
If something like this is what happened, it is a case of mere children's play going somewhat out of hand - how is this a challenge to the guise of the good-principle, something which Augustine should remember with such horror? Thus reconstructed, the answer to the question of how the kids came to adopt a plan that did not make sense by anybody's light is that the joint action was not guided by any such plan, but that the plan emerged from the coincidental combination of more or less spontaneous and differing individual views of what it is they could be doing together. The Pear Theft is thus clearly a joint action, but it cannot be accounted for in terms of an execution of a joint plan, because the purpose of the venture emerged only over the course of the act rather than being the guiding principle behind the act. If, under normal circumstances, people decide to act jointly and do their own part on the base of an agreed-upon plan, this rational order is inverted in this case: there is a manifest will to participate, but what it is in which they participate emerges only on the base of the individual contributions. The joint goal is not first in the act, but comes last, and emerges coincidentally, as it were. The rational order is perverted. By the same token, the joint action is not a proper joint action, but rather a corrupted form, or travesty, of a joint action - because while cooperating intensely, the participants quite literally don't know what they are doing together. While the emerging structure looks purposive, and thus like a proper joint action, the purpose is actually a matter of chance.

The account I have given is thus compatible with the view that (proper) action, joint or individual, is under the guise of the good, while still reconstructing the case as a challenge to that principle; it is a challenge in virtue of the feature that marks it as a corrupted form of joint action.

In terms of a travesty of joint action that is deficient in that it is not based on any however rudimentary form of joint reasoning or rational adoption of a joint goal, the Pear Theft is thus entirely unguided by any conception of the good - the purpose of the act is left to mere chance. Yet as such, this reconstruction does not give us an account of an action that is guided by the bad. After all, if our reconstruction of the act as rationally unguided, the boys might easily have ended up stealing some freshly baked pie rather than with their nonsensical act of feeding pigs.

In order to see how the act might have actually been under the guise of the bad rather than just unguided by any conception of the good, it is important to bring Augustine's first line of explanation more into sharper focus. So far, all we have invoked from this line of Augustine's account is some "thrill of doing something illicit" on the side of the participants. But where does the sort of hyperbolic pride, the desire to assert one's absolute autonomy in terms of the ability to systematically violate any norm enter the picture? Have we lost sight of this line of explanation which features so prominently in Augustine's account as well as in traditional interpretations? Indeed, it seems that the idea of imitatio dei and absolute autonomy is rather far from how we have depicted the kids' motivational set-up. So where is the connection? To see it, I suggest to include an episode in book III of the Confessions, where we find an instructive example that may shed some light on how a combination of peer bonding and the desire to assert one's agency might have played out in the Pear Theft case. ${ }^{4}$ In book III, Augustine has moved from his home town Thagaste to study in Carthage. He is no longer

\footnotetext{
${ }^{4}$ The idea to draw on the eversores-episode in book III for an understanding of the Pear Theft is not new; Wills (2002) developed this lead in rich and insightful historical detail. Wills shows convincingly that two passages in book II - Augustine's remarks on Sallust's Catiline and his reflections on bad friendship that echo Cicero's views - are a decisive link to the eversores-episode. My interpretation, however, differs from Wills' in that it yields a guise of the bad-account.
} 
engaged in the sort of "children's play getting out of hand" of the sort of the Pear Theft. Rather, he is now confronted, among his fellow students, with a (rather rudimentary) version of a youth gang activity. The group of students described in III, iii, are sort of a gang to whom Augustine was loosely affiliated, who spend their time "attacking the modesty of strangers", "vexing them with abusing and jeering upon no occasion" (gratis) - playing bad random pranks on people (especially professors) by exposing them to ridicule and shame. In his account of the kind of consortium at hand here, Augustine emphasizes two features. First, and most obviously, Augustine says that "nothing in the world can be like the very actions of the devil himself, than this behavior of theirs". Second, he emphasizes the importance of their selfascribed collective identity by emphasizing that they prided themselves in the name of their group, the "eversores", or "Subverters".

How this case elucidates how the purpose of a consortium, unlike in the case of the "young scoundrels" of the Pear Theft, did not just happen to be bad, but had to be so in a way that makes the act not just unguided by any guise of the good, but actually under some guise of the bad is the following - the key is in the kind of self-ascribed identity that Augustine emphasizes. Imagine a group of young adolescents, who are not merely driven by the intense desire to be acting together, but who are very much concerned with who they are in such a way that it is important to them to establish, and assert, their belonging to a particular and distinguishable group whose identity matters to them. What these agents care most about is to be down with a gang with a strong and recognizable identity as that group, and with their individual social identity as that group's members. It is not just smooth interaction within a joint activity that pleases them, but rather, the sense of being somebody as part of something larger, a discernable group of like-minded individuals. At this stage, adolescents like to discern themselves, collectively, from others; it is not uncommon for them to give themselves a name, as in Augustine's case, or turn some pejorative label given to them by outsiders and turn it around to wear it with pride. Other likely ways to express their sense of collective identity is to use offensive signs. They tend to stick together, and to isolate themselves from others, e.g. by gathering at specific places which they occupy and defend as theirs. As their behavior shows, for these adolescents, the distinction between them, collectively, and everybody else becomes salient. What they want to be, jointly, is this group, to constitute a unified whole with a strong sense of not just being anybody. It seems obvious that one way in which the status of the group as a group can be established is by exerting the power of their joint agency, together: See what we can do! Moreover, the sense of collective identity is increased if the question of in virtue of what a particular goal seems worthwhile pursuing is determined from their collective perspective - and not according to any received universal standards. What is worthwhile doing is what they accept as such; the standards of value at work in action have to be theirs. Thus it is obvious that the adolescents cannot wish to be, individually or collectively, good boys; in order to establish that their values are truly theirs, they will be particularly concerned with making the difference between what is generally considered acceptable and what they accept as obvious as possible. Thus it is no coincidence that they do not want to be good boys. They want to be badasses. It becomes important now for them to do what is wrong, as this establishes that the agency behind the act is expressive of the group specific evaluative perspective, and thus asserts the group's identity - a sort of collective hyperbolic autonomy. In the light of such motivation, whatever they do is now systematically and geared towards a violation of universal - and thus moral - standards, and is 
thus not just incidentally bad in the way of joint action that is unguided by the good, but rather essentially bad, or sub specie mali.

It is certainly true that the phenomenon to which Augustine draws his reader's attention in the account of "the Subverters" does not account for any form of youth gang activity; it focuses on a special form of youth gang. Sociological research has rightly pointed out that youth gangs assemble around a great variety of issues, and that their make-up and network structure differ widely (cf., e.g., Hazlehurst/Hazlehurst [eds.] 1998; Esbensen and Maxson [eds.] 2012). It is only in specific cases that it is not just from the critical outsider perspective that the gang's culture appears as anti-social. In this case, being "badasses" our "outlaws" is a label worn by the members with pride, as it captures rather nicely what the gang is about. Cases of this kind differ from other cases, such as the sociologically most studied case, gangs that provide common goods in disintegrated communities. It is not a mere outsider's prejudice that fails to be based on an adequate understanding of what the group is about that results in the harsh judgment of anti-social behavior. Rather, this conception figures prominently in the members' self-conception in some version. The gang's disruptiveness and destructive nature is not, in these cases, a misunderstanding of the group's true aims. Rather, it is an adequate description of a core feature of what it is about.

Gangs of the kind of the "Subverters" - self-professed "badass" gangs - may rarely occur in pure form, but it is hard to deny that such cases exist. While current research is largely focused on research on the complex interplay between different sorts of causes that promote the emergence of youth gangs, as well as on the different kinds of internal structuring and network building, the old topic of the values around which gangs are formed seems to have sunk a bit in the background. Current social identity theory has revealed a wealth of insight about in-group bias, but it has largely remained silent about the specifics of the formation of the group ethos that embodies the group's identity. But this is exactly Augustine's topic, thus reconstructed, and if we combine his account of "The Subverters" with his account of agential pride, we seem to come close to an account of intentional evil. Groups whose members value their particular collective identity as set against what is recognized as having value for anybody.

The difference between what's right for anybody, and what is the thing to do for them, as this particular group of theirs, involves more than just the difference between them and society. Not being just anybody is something the group does not simply has to assert against society, but also against themselves: each of the members has to renounce what he or she is, independent of the community, in order to endorse the particular identity of the gang as its member. The disruption, subversion, and violence with which gangs of this kind afflict their wider communities is the same disruption, subversion and violence they inflict on each of their members upon admission to the group. It is often the case that as a ritual of acceptance, youth gangs require of their prospective members to act against their previously held convictions and inclinations, e.g., by willingly exposing themselves to ridicule, by eating disgusting things, or by betraying some of their previously held values. Under labels such as "hazing" or "bastardization", this is known even in groups whose identities are not per se anti-social. The often rather improvised rites of passage in fraternities and sororities as well as academic sports teams offer ample and widely publicized evidence for this phenomenon. At the surface of it, such practices of "making the team" (cf. Johnson and Holman 2004) serve to establish the prospective member's motivation to join the group, and to subject new members to the existing power structure. A deeper purpose of this is to establishing the individual's willingness to let go of previously held standards, to consider as valuable, qua member of the group, 
what he or she disvalued, as an independent individual - to let go of who he or she was, to become somebody new, "one of us".

This might play an important part in why adolescents often change in so profound and radical a way when they become members of a gang, often involving the assertion of new preferences that are in direct opposition to previously held attitudes. The members of youth gangs do not only purposefully offend "other people", "the family", "the society"; it should not be overlooked that the very same sort of disruption, and sometime even violence, they tend to impose on the communities within which they emerge, they also commit onto their own participants, when they become a member, e.g. by imposing distancing from their families, who are left at a loss as to the question of how their child, whose character and inclinations they know so well, could suddenly be so intent on something like this.

This double distinction explains why, so often, youth gang acts tend to be not only wrong in terms of the normative standards of the wider society, but also inexplicable from the point of view of the values held by the individual participating members. The rational gap in the acts at stake, the fact that it is not possible to account for the goal in terms of what the agents value, has importance to the agent in that it expresses the agent's new identity as a team member.

The step from incidental to intentional evil, from "children's play getting out of hand" to "youth gang crime" may be a gradual one, and certainly, cases in which gang cultures are purely anti-social are rare. However, however weak the anti-social ingredient may be, such identities involve an element in virtue of which the acts in which such identities are asserted may be seen as "under the guise of the bad": as an assertion of a group's "badass" identity. By contrast to the Pear Theft scenario of children's play getting out of hand, is now not just incidentally so that the act in which the agent participates is wrong, and that the goal is not expressive of the participant's own evaluative states; rather, it is essentially so.

The way in which this account of how Augustine's two lines of motivational explanation of the Pear Theft work together is that the individual motivation to be down with the gang is combined with the desire to express a hyperbolic sort of independence at the collective level. And the way in which this preserves a sense in which such action is under the guise of the bad is that even though there are reasons for the individuals to participate, there is a sort of collective agency emerging between them that is not guided by any reasoning, but systematically geared towards violation of moral norms.

Acknowledgements Open access funding provided by University of Vienna.

Open Access This article is distributed under the terms of the Creative Commons Attribution 4.0 International License (http://creativecommons.org/licenses/by/4.0/), which permits unrestricted use, distribution, and reproduction in any medium, provided you give appropriate credit to the original author(s) and the source, provide a link to the Creative Commons license, and indicate if changes were made.

\section{References}

Anscombe GEM (1963) Intention, 2nd ed. Blackwell, Oxford

Aquinas T (2003) On evil. Transl. By Regan R. Oxford University Press, Oxford

Boyce J (2014) Born bad. Original sin and the making of the western world. Schwartz, Collingwood

Coliva A (2015) How to commit Moore's paradox. J Philos 112(4):169-192

Esbensen F-A, Maxson CL (eds) (2012) Youth gangs in international perspective. Results from the Eurogang Program of Research. Springer, Dordrecht 
Hazlehurst K, Hazlehurst C (eds) (1998) Gangs and youth subcultures: international explorations. Transaction Publishers, New Brunswick

Jaspers K (1962) Augustine and Plato. Harcourt, Brace \& World, New York

Johnson J, Holman M (eds) (2004) Making the team: inside the world of sport initiations and hazing. Canadian Scholar's Press, Toronto

La Croix R (1984) The paradox of Eden. Int J Philos Relig 15(3):171

MacDonald S (1996) Petit larceny, the beginning of all sin: Augustine's theft of the pears. In: Mann WE (ed) Augustine's confessions. Critical essays. Lanham, Rowman and Littlefield, pp 45-70

Matthews G (2005) Augustine. Blackwell, London

Moore GE (1993) Moore's paradox. In: Baldwin T, Moore GE (eds) Selected writings. Routledge, London, pp 207-212

O’Connell RJ (1969) St. Augustine's confessions. The odyssey of soul. Belknap Press, Cambridge

Riesman D, Glazer N, Denney R (1950) The lonely crowd. A study of the changing American character. Yale University Press, New Haven

Russell B (2004 [1946]) History of western philosophy. Taylor \& Francis, London

Schmid HB (2005) Wir-Intentionalität. Kritik des ontologischen Individualismus und Rekonstruktion der Gemeinschaft. Alber Verlag, Freiburg i. Br

Schmid HB (2009) Plural action - essays in philosophy and social science. Springer, Dordrecht

Schmid HB (2016) On knowing what We're doing together: groundless group self-knowledge and plural selfblindness. In: Brady M, Fricker M (eds) The epistemic life of groups: essays in the epistemology of collectives. Oxford University Press, Oxford, pp 51-74

Starnes C (1990) Augustine's conversion. Wilfrid Laurier University Press, Ontario, A Guide to the Argument of Confessions I-IX

Stern HS (1958) The knowledge of good and evil. Vetus Testamentum 8(4):405-418

Stocker M (1979) Desiring the bad. An essay in moral psychology. J Philos 76(12):738-753

Vaught CG (2003) The journey toward god in Augustine's confessions: books I-VI. SUNY Press, Albany

Velleman JD (1992) The guise of the good. Nous 26(1):3-26

Wills G (2002) Augustine's pears and the nature of sin. Arion: A Journal of Humanities and the Classics 10(1): 57-66 